\title{
State Responsibility and Community Interest in International Energy Law: A European Perspective
}

\author{
Danae Azaria
}

\begin{abstract}
Treaties dominate international energy law, meaning the rules of public international law that govern energy activities and their effects. This raises the question about the relationship of treaties, and particularly those on energy trade, with the law of international responsibility. This article uses a European angle to contextualise the importance of this question. EU Member States are major oil and gas importers from third states. The EU and Member States are party to treaties with third states that apply to energy trade, carriage and investment. Whether treaty obligations, undertaken and owed to the EU and/or Member States vis-à-vis third states, are of bilateral, interdependent or community interest nature determines whether the EU and/or a Member State have standing to invoke the responsibility of a third state for a breach of an energy-related obligation as well as their remedial rights and the means by which they may implement responsibility. At the same time, because energy access is vital for states, suspending compliance with obligations in the energy sector is often preferred as a permissible response to wrongfulness carrying significant effects and persuasiveness. The nature of obligations of international energy law may determine whether suspending compliance with such obligations can be a lawful countermeasure either by the EU and/or Member States against a third state, or by a third state against the EU and/or Member States.
\end{abstract}

\section{Keywords}

State responsibility, international energy law, World Trade Organization, pipeline treaties, human rights

\section{Introduction}

The European Union (EU) Member States are major oil and gas importers. The EU imports 90 per cent of the oil and 66 per cent of the gas that it consumes. ${ }^{1}$

* Lecturer in Law, Faculty of Laws, University College London (UCL), email: d.azaria@ucl.ac.uk. An earlier draft of this article was presented at the CJICL Young Scholar's Lecture at the Lauterpacht Centre for International Law, University of Cambridge. This article is based on the author's research for the monograph, Treaties on Transit of Energy via Pipelines and Countermeasures (OUP 2015).

1 See generally 'Energy Security Strategy' (European Commission) <https://ec.europa.eu/ energy/en/topics/energy-strategy/energy-security-strategy> accessed 28 September 2016. 
The dependence of EU Member States on imports of different energy sources has, to varying degrees, existed for decades. The exporting and transit states of these sources of energy have also changed over time. ${ }^{2}$ Despite this dependence, it was not until the Treaty for the Functioning of the European Union (TFEU), that a new Title on Energy was added. ${ }^{3}$ The Title comprises only one provision-Article 194which operates as a separate basis for energy-related EU legislation. However, even before the insertion of this provision, EU energy law had been expanding mainly with a view to creating an internal energy market and securing oil and gas supplies, with further developments to be expected as the European Commission has made a new proposal for an 'Energy Union.'

Given the need for energy imports, the relationship of the EU and Member States with third states in the energy sector has been perceived as critical for the development of the internal energy market, as well as for securing supply. ${ }^{6}$ The modern significance of this relationship is illustrated by the effects of the 2009 gas crisis on the European gas market that occurred owing to a dispute concerning exports of gas from Russia to Ukraine and being transited through Ukraine. ${ }^{7}$ In terms of factual effects, industrial and household consumers were left without gas for days. ${ }^{8}$ In terms of legal impact, the conduct of third states triggered the with Major Oil and Gas Supplying Countries (Hart 2007) 38-64.

3 Consolidated Version of the Treaty on the Functioning of the European Union [2008] OJ C115/47 (TFEU); For the reasons behind the reluctance of Member States to have a common energy policy, see Haghighi (n 2) 46-53, 56-62.

Until the insertion of this provision, EU energy-related legislation was adopted mainly on the environmental and internal market bases and mainly through harmonisation. See generally Christopher Jones (ed), EU Energy Law, vol 1 (4th edn, Claeys \& Casteels Publishing 2016) 1-9; Angus Johnston and Guy Block, EU Energy Law (OUP 2012) 4-6.

5 See Commission, 'A Framework Strategy for a Resilient Energy Union with a Forward-Looking Climate Change Policy' COM (2015) 80 final.

6 Haghighi (n 2) 63.

7 Dan Bilefsky and Andrew E Kramer, 'Deal to End Russia's Cutoff of Gas Remains Uncertain' The New York Times (New York, 9 January 2009) <http://www.nytimes.com/2009/01/10/world/ europe/10gazprom.html> accessed 28 September 2016; For an analysis of the 2009 dispute between Ukraine and Russia, see Danae Azaria, Treaties on Transit of Energy via Pipelines and Countermeasures (OUP 2015) 4-5, 90-93. European Commission, 'Member State General Situation According to Significance of Impact, Memo/09/3)' (9 January 2009) <http://europa.eu/rapid/pressReleasesAction. do?reference=MEMO/09/3\&type $=$ HTML $>$ accessed 28 September 2016. 
development of EU secondary legislation - the 2009 crisis led to the adoption of the 2010 Gas Security of Supply Regulation.'

The relationship with third states is governed by international law. The EU and Member States are party to treaties with third states that apply to energy trade and investment, and Member States conclude treaties with third states so as to diversify sources and routes of supply. This treaty practice-partly driven by an effort to secure uninterrupted energy supply-raises a number of legal questions. ${ }^{10}$ This study analyses the relationship between treaties concerning energy activities and the law of international responsibility. More specifically, the study focuses on the treaties that regulate the trade of energy. It explains that the nature of treaty obligations, which are undertaken and owed to the EU and/or Member States visà-vis third states, determines whether the EU and/or a Member State has standing to implement the responsibility of a third state for a breach of an energy-related obligation. It also determines which remedial rights they have and by which means they can implement the responsibility of a third state. At the same time, because access to energy is vital for states-their economies and the survival of their populations depend on it ${ }^{11}$-suspending compliance with obligations in the energy sector rank highly among the permissible responses to wrongfulness carrying significant persuasiveness. The nature of obligations of international energy law, meaning the rules of public international law that govern energy activities and their effects, ${ }^{12}$ may determine whether suspending compliance with such obligations can be a lawful countermeasure. Such countermeasure may be taken either by the EU and/or Member States against a third responsible state, or by a third state against the EU and/or Member States.

These issues are of exceptional practical importance to the EU, its Member States and its neighbourhood, as they lie at the heart of energy security considerations. Which Contracting Parties to the Energy Charter Treaty (ECT) or Members of the World Trade Organization (WTO), for example, were entitled

9 Council Directive (EU) 994/2010 of 12 November 2010 concerning measures to safeguard security of gas supply and repealing Council Directive (EC) 2004/67 [2010] OJ L295/1 recitals $26-27$.

10 Questions that fall beyond the scope of this study include the allocation of external competence in relation to energy trade, the compatibility of EU law with treaties between Member States and third states, and the relationship between these treaties and customary international law.

11 Case 72/83 Campus Oil Limited and Others $v$ Minister for Industry and Energy and Others [1984] ECR 2727, para 34.

12 Catherine Redgwell, 'International Regulation of Energy Activities' in Martha Roggenkamp and others (eds), Energy Law in Europe (3rd edn, OUP 2016) 16. 
to resort to dispute settlement under the ECT or the WTO Agreement against Ukraine or Russia in relation to the 2009 incident alleging breaches of transit or export obligations (respectively)? ${ }^{13}$ Would Ukraine have been able lawfully to suspend compliance with its transit obligations under the WTO or the ECT in response to Russia's unlawful annexation of Crimea with consequences for the EU and its Member States? Can a Member State, which is party to a bespoke pipeline treaty with a third state, suspend energy flows via the pipeline in response to a breach of an obligation owed to it by that third state?

The following analysis will first determine the nature of some primary obligations of international energy law that are of relevance to EU and/or Member States. Second, it will examine how secondary rules on energy-related countermeasures take into account the nature of primary obligations. ${ }^{14}$ The analysis will place international energy law and the energy security concerns of the EU and Member States within the broader field of public international law. The European angle is a context that assists in better understanding the application of international responsibility in the context of international energy law.

\section{From Bilateralism to Community Interest in International Energy Law: Treaties of European Concern}

In early January 2009, the transit and export of gas to EU Member States were interrupted arguably contrary to Ukraine's transit obligations (under the WTO Agreement and the ECT) and Russia's export obligations (under the ECT). Yet, there UNTS 95 (ECT); Marrakesh Agreement establishing the World Trade Organization (adopted 15 April 1994, entered into force 1 January 1995) 1867 UNTS 3. The EU and Member States were ECT Contracting Parties and WTO Members, as was Ukraine. Russia was provisionally bound by the ECT at the time of the dispute, but Russia was not a WTO Member. Russia acceded to the WTO Agreement on 22 August 2012. Russia's provisional application of the ECT ceased to be in effect since 19 October 2009 (pursuant to ECT art 45(3)(a)). On 20 August 2009, Russia expressed its intention not to become a party to the ECT. For Russia's provisional application of ECT, see Yukos Universal Limited (Isle of Man) v The Russian Federation, PCA Case AA227, Interim Award on Jurisdiction and Admissibility, 30 November 2009, para 394.

14 Primary rules determine the conduct of a state, while secondary rules deal with the consequences of the breach of primary rules. For an explanation of the distinction between the two, see ILC, 'Report of the International Law Commission on the Work of its Twenty-second Session' (4 May-10 July 1970) UN Doc A/8010/Rev 1, 306, para 66.c. 
is no evidence that the EU or Member States formally invoked the responsibility of either of the two states by requesting cessation of the wrongful act or reparation, by resorting to dispute settlement or by resorting to countermeasures. ${ }^{15}$ Rather, on 10 January 2009, Russia, Ukraine and the European Commission signed the Agreement on Monitoring of Natural Gas through Ukraine, pursuant to which international monitoring staff (with strictly fact-finding competence) were dispatched to metering stations at the Russia-Ukraine border in Ukraine and Russia. ${ }^{16}$ However, the fact that responsibility was not invoked does not perforce mean that responsibility has not been engaged; nor does it necessarily mean that the EU and/or Member States lacked standing to invoke responsibility. Invoking international responsibility is discretionary. ${ }^{17}$

In 2001, the International Law Commission (ILC) adopted the Articles on the Responsibility of States for Internationally Wrongful Acts (ASR) ${ }^{18}$ and submitted them to the General Assembly that commended them to the governments. ${ }^{19}$ The ASR generally represents customary international law concerning the entitlement to invoke responsibility. ${ }^{20}$ Standing to invoke responsibility is premised on a tripartite classification of primary obligations. International obligations are classified on the basis of the question 'to whom are these obligations owed?'

15 Invoking responsibility involves claims of 'relative formality', such as recourse to dispute settlement or countermeasures. ILC, 'Text of the Draft Articles on Responsibility of States for Internationally Wrongful Acts with Commentaries Thereto' (23 April-1 June and 2 July-10 August 2001) UN Doc A/CN.4/SER.A/2001/Add.1 (Part 2), 117.

16 On 19 January 2009, Gazprom and Naftogaz signed 10-year supply and transit contracts. The $\mathrm{EU}$ and Member States were informed of the agreement, without participating in negotiations. On 20 January 2009, supplies to, and transit via, Ukraine began. See José Manuel Durão Barroso, 'Statement of President Barroso on the resolution of the Ukraine-Russia Dispute' (European Commission, 20 January 2009) <http://europa.eu/rapid/pressReleasesAction. do? reference $=$ SPEECH/09/12\&format $=$ HTML\&aged $=0$ \&language $=E N \&$ guiLanguage $=e n>$ accessed 28 September 2016. On 22 January 2009, gas flows to all importing states returned to the levels before the interruption.

17 For possible reasons relating to the legal architecture of WTO and ECT dispute settlement mechanisms, see Azaria (n 7) 168-72, 177-84.

18 ILC (n 15) 26-30.

19 UNGA Res 56/83 (28 January 2002) UN Doc A/RES/56/83.

20 ILC (n 15) 117-19, 126-28; The ICJ has followed the ASR's position concerning standing to invoke responsibility for breaches of erga omnes partes obligations in Questions relating to the Obligation to Prosecute or Extradite (Belgium v Senegal) (Judgment) [2012] ICJ Rep 2012, paras $67-70$. 
First, some obligations are 'bilateral'. These obligations are owed in pairs between the parties. When they are grounded in multilateral norms, such as a multilateral treaty, they may be called 'bilateralisable'. In the latter case, the multilateral norm creates bundles of bilateral relationships. ${ }^{21}$ An example is that of innocent passage through the territorial sea. ${ }^{22}$ In case of a breach, the individually injured state may invoke responsibility, including by recourse to countermeasures. ${ }^{23}$

Second, other obligations are 'interdependent', meaning obligations owed to a group of states collectively but premised on 'global reciprocity. ${ }^{24}$ Non-performance by one permits everyone else not to perform - a paradigmatic example is obligations of disarmament. Under the ASR, breaches of a certain character may change radically the position of all other states to whom this type of obligation is owed with respect to the further performance by those other states of the obligation. ${ }^{25}$ Accordingly, the breach allows all other states to which the obligation is owed to invoke responsibility, as injured states, including by recourse to countermeasures. ${ }^{26}$

Third, community interest obligations, which are obligations owed indivisibly to all states for the protection of a collective interest (erga omnes obligations) or to a group of states established for the protection of a collective interest of the group (or even for a wider common interest) above the individual interests of the group (erga omnes partes obligations). ${ }^{27}$ These are genuinely multilateral obligations. ${ }^{28}$ In case of a breach, the specially affected state is the injured state and may invoke responsibility, including by recourse to countermeasures. ${ }^{29}$ States other than the injured state may claim cessation of the wrongful act and assurances and guarantees

Bruno Simma, 'Bilateralism and Community Interest in the Law of State Responsibility' in Yoram Dinstein (ed), International Law at a Time of Perplexity: Essays in Honour of Shabtai Rosenne (Martinus Nijhoff Publishers 1989) 822-23.

22 James Crawford, 'Multilateral Rights and Obligations in International Law' (2006) 319 Recueil des Cours 325. ILC (n 15) arts 42(a), 49. Linos-Alexander Sicilianos, 'The Classification of Obligations and the Multilateral Dimension of the Relations of International Responsibility' (2002) 13 EJIL 1127, 1134-36; ILC (n 15) 117-18, note 669. 
of non-repetition. ${ }^{30}$ As a matter of progressive development, the ASR suggest that a state other than the injured state may claim reparation in the interest of the injured state, assuming that an injured state exists. ${ }^{31}$ It is questionable whether states other than the injured state may resort to countermeasures. ${ }^{32}$

According to the ILC Commentary to the ASR, the determination of the nature of the obligation takes place by interpreting the primary rule. ${ }^{33}$ In the absence of a reasonable alternative, it is logical to argue that, at least in relation to treaty obligations, the customary rules on treaty interpretation set forth in Articles 31 and 32 of the Vienna Convention on the Law of Treaties (VCLT) are to be used. ${ }^{34}$ Furthermore, international case law has placed emphasis on the treaty's object and purpose in order to identify the nature of treaty obligations, ${ }^{35}$ and scholars have suggested that inter se modifications are prohibited in cases of treaties that establish community interest obligations. ${ }^{36}$

Reciprocity dominates economic activities in the energy sector. Prior to the rise of multilateral treaties that either specifically deal with energy trade (eg ECT) or also apply to energy trade (eg GATT annexed to the WTO Agreement), energy trade had fallen within the scope of bilateral treaties on friendship, navigation and

30 ibid art 48(2)(a).

31 ibid art 48(2)(b).

32 ibid art 54. See also ILC (n 15) 129, 137, 139; For an argument that countermeasures of states other than the injured state are permitted under lex lata, see Linos-Alexandre Sicilianos, 'Countermeasures in Response to Grave Violations of Obligations Owed to the International Community' in James Crawford and others (eds), The Law of International Responsibility (OUP 2010) 1146-48.

33 ILC (n 15) 118; Special Rapporteur Fitzmaurice in his work on the law of treaties had similarly suggested that the nature of treaties is determined by the 'correct interpretation of the treaty according to its terms': ILC, 'Fourth Report on the Law of Treaties' (1959) UN Doc A/CN.4/120 para 18.

34 Vienna Convention on the Law of Treaties (adopted 23 May 1969, entered into force 27 January 1980) 1155 UNTS 331 (VCLT).

35 S.S. Wimbledon (United Kingdom, France, Italy and Japan v Germany) (Judgment) [1923] PCIJ Rep Series A No 1; Questions relating to the Obligation to Prosecute or Extradite (Belgium v Senegal) (Judgment) [2012] ICJ Rep 2012; In relation to the EU founding treaties, see Case 26/62 NV Algemene Transport-en Expeditie Onderneming van Gend \& Loos v Netherlands Inland Revenue Administration [1963] ECR 1, 12.

36 Individual Opinion by M. Anzilotti, Customs Regime between Germany and Austria (Advisory Opinion) (1931) PCIJ Rep Series A/B No 41, 64; Separate Opinion of Judge van Eysinga, The Oscar Chinn Case (United Kingdom v Belgium) (Judgment) (1934) PCIJ Rep Series A/B No 63, 131. 
commerce. A case concerning the breach of such obligations that found its way to the International Court of Justice (ICJ) was the Oil Platforms case which was couched in terms of energy commerce. ${ }^{37}$ However, treaty obligations in this area of international law may protect the community interests of treaty parties. The following analysis classifies obligations relevant to energy activities in treaties to which either the EU and/or Member States are parties along with third states. These are examined in the following sequence: the WTO Agreement, the ECT, and bespoke pipeline treaties: the Nabucco Pipeline Agreement ${ }^{38}$ (Nabucco Agreement), the Trans-Adriatic Pipeline Treaty ${ }^{39}$ (TAP Treaty) and the bilateral treaties for the South Stream pipeline. ${ }^{40}$

Oil Platforms (Islamic Republic of Iran $v$ United States of America) (Preliminary Objection, Judgment) [1996] ICJ Rep 1996, 817, para 38; Oil Platforms (Islamic Republic of Iran v United States of America) (Judgment) ICJ Rep 2003, 161 paras 23-84. Agreement among the Republic of Austria, the Republic of Bulgaria, the Republic of Hungary, Romania and the Republic of Turkey Regarding the Nabucco Project (signed 13 July 2009) $<$ https://www.ris.bka.gv.at/Dokumente/BgblAuth/BGBLA_2010_III_57/COO_2026_100_ 2_605048.pdf> accessed 28 September 2016.

39 Agreement among the Republic of Albania, the Hellenic Republic and the Italian Republic relating to the Trans Adriatic Pipeline Project (signed 13 February 2013, entered into force 5 January 2014) <http://nomoi.info/ФEK-A-267-2013- $\sigma \varepsilon \lambda-93 . h t m l>$ accessed 28 September 2016.

40 Treaties for the South Stream pipeline between Russia and EU Member States (abbreviated): Intergovernmental Agreement between the Government of the Republic of Bulgaria and the Government of the Russian Federation on Cooperation in the Construction and Operation of the Gas Pipeline in the Territory of Bulgaria (signed 18 January 2008); Intergovernmental Agreement between the Government of the Republic of Hungary and the Government of the Russian Federation on Cooperation in the Construction and Operation of the Gas Pipeline in the Territory of Hungary (signed 28 February 2008); Agreement between Government of the Hellenic Republic and the Government of the Russian Federation on Cooperation in the Construction and Operation of the Gas Pipeline in the Territory of the Hellenic Republic (signed 29 April 2008); Intergovernmental Agreement between the Republic of Slovenia and the Government of the Russian Federation on Cooperation in the Construction and Operation of the Gas Pipeline in the Territory of the Republic of Slovenia (signed 14 November 2009); Intergovernmental Agreement between the Government of the Republic of Austria and the Government of the Russian Federation on Cooperation in the Construction and Operation of the Gas Pipeline in the Territory of the Republic of Austria (signed 24 April 2010); Intergovernmental Agreement between the Government of the Republic of Croatia and the Government of the Russian Federation on Cooperation in the Construction and Operation of the Gas Pipeline in the Territory of the Republic of Croatia (signed 2 March 2010) (Croatia was not an EU Member State when it concluded this treaty with Russia). 


\subsection{The WTO Agreement and Trade in Energy Goods}

Under the 1947 General Agreement on Tariffs and Trade (1947 GATT) ${ }^{41}$ disputes concerning energy trade were not prominent. ${ }^{42}$ There is no agreement specifically dedicated to energy trade annexed to the WTO Agreement. In the first two decades since the entry into force of the WTO Agreement, disputes concerning energy trade did not give rise to proceedings under the Dispute Settlement Understanding (DSU). ${ }^{43}$ However, the scope of application of the WTO Agreement, including its annexes, such as the 1994 General Agreement on Tariffs and Trade (GATT), ${ }^{44}$ encompasses some aspects of the energy sector. For example, freedom of transit (GATT Article V) and the prohibition of import and export restrictions (GATT Article XI) apply to oil and gas products. ${ }^{45}$ Furthermore, disputes relating to the energy (or mineral resources) sector are increasingly brought under the WTO DSU. ${ }^{46}$ Given the interconnection of energy markets, standing to invoke responsibility for breaches of trade obligations in the energy sector is important in relation to energy-related disputes.

41 General Agreement on Tariffs and Trade (adopted 30 October 1947, provisionally applicable 1 January 1948) 55 UNTS 194. The provisional application of 1947 GATT was terminated one year after the entry into force of the WTO Agreement, pursuant to the Decision of 8 December 1994 adopted by the Preparatory Committee for the WTO and the Contracting Parties to GATT 1947 on "Transitional Co-existence of the GATT 1947 and the WTO Agreement" (PC/12, L/7583).

42 The only 1947 GATT case that dealt with energy activities was Report of the Panel on USTaxes on Petroleum and Certain Imported Substances (1987) GATT BISD 34S/136.

43 Understanding on Rules and Procedures Governing the Settlement of Disputes, Annex 2 to the Agreement establishing the World Trade Organization (adopted 15 April 1994, entered into force 1 January 1995) 1869 UNTS 401.

44 General Agreement on Tariffs and Trade, Annex IA to the Agreement establishing the World Trade Organization (adopted 15 April 1994, entered into force 1 January 1995) 1867 UNTS 3; annexes to the WTO Agreement expressly constitute an integral part of the WTO Agreement (Article II, paragraph 2 of the WTO Agreement); GATT is legally distinct from 1947 GATT, pursuant to Article II(4) of the WTO Agreement.

45 Azaria (n 7) 30-35.

46 WTO, Canada: Certain Measures Affecting the Renewable Energy Generation Sector-Report of the Appellate Body (6 May 2013) WT/DS412/AB/R; WTO, Appellate Body Report, China: Measures Related to the Exportation of Various Raw Materials-Report of the Appellate Body (22 February 2012) WT/DS394/AB/R, WT/DS395/AB/R and WT/DS398/AB/R; WTO, China: Measures Related to the Exportation of Rare Earths, Tungsten, and Molybdenum-Report of the Appellate Body (26 March 2014) WT/DS431/R. Indicative pending cases: WTO, European Union and its Member States-Certain Measures Relating to the Energy Sector-Request for Consultation by the Russian Federation (8 May 2014) WT/DS476/1; WTO, European Union 
The nature of WTO obligations has been considered by a Panel in EC-Bananas ${ }^{47}$ and by an Arbitrator in US-Tax Treatment for 'Foreign Sales Corporations. ${ }^{48} E C$-Bananas dealt with standing to bring a claim under the WTO DSU for a breach of the GATT. In its reasoning, the Panel did not expressly make a finding that the GATT obligations are bilateralisable, erga omnes partes, or interdependent. ${ }^{49}$ Rather, its reasoning was based on the factual interconnectedness of international markets ('interdependence of global economy') and the risk of economic impact, including in the form of supplies and prices, faced by any other WTO member in cases where violations of GATT occur. In support of its findings, the Panel cited the Judgment of the Permanent Court of International Justice (PCIJ) in S.S. Wimbledon, ${ }^{50}$ as well as the provisionally adopted ILC Draft Articles on State Responsibility (1996), ${ }^{51}$ particularly Article 40(e) and (f), which encompass bilateral, interdependent, erga omnes and erga omnes partes obligations respectively. By referring to community interest obligations without distinguishing among these bases, the Panel opened the debate about whether GATT obligations are erga omnes partes. ${ }^{52}$ However, the fact that the Panel cited the page of the S.S. Wimbledon Judgment where the PCIJ addressed the issue of jurisdiction (and, by implication, standing), ${ }^{53}$ rather than the judgment's operative part, which touches implicitly on the nature of the primary obligations in question, offers support to the view that rules on standing in the WTO Agreement, including its Annexes, may be generous and unconnected to the nature of the primary obligations therein.

and Certain Member States-Certain Measures on the Importation and Marketing of Biodiesel and Measures Supporting the Biodiesel Industry-Requests for Consultation by Argentina (23 May 2013) WT/DS459/1.

WTO, European Communities: Regime for the Importation, Sale and Distribution of BananasComplaint by the United States (22 May 1997) WT/DS27/R/USA, as modified by the Report of the Appellate Body (25 September 1997).

WTO, United States-Tax Treatment for 'Foreign Sales Corporations'-Recourse to Arbitration by the US under Article 22.6 of the DSU and Article 4.11 of the SCM Agreement-Decision of the Arbitrator (30 August 2002) WT/DS108/ARB.

49 WTO, European Communities (n 47) para 7.50.

50 S.S. Wimbledon (n 35).

51 ILC, 'Report of the International Law Commission on the Work of its 48th Session' (6 May-26 July 1996) UN Doc A/51/10, 58. WTO, European Communities (n 47) para 7.50. tribunals as preliminary objections. On the distinction between jurisdiction and admissibility, see Hochtief AG $v$ the Argentine Republic ICSID Case ARB/07/31, Decision on Jurisdiction, 24 October 2011, paras 90-96. 
In US-Tax Treatment for 'Foreign Sales Corporations', the Arbitrator did not deal with standing, but with the quantitative amount of the countermeasure agreed between the parties to the dispute. He explained that the prohibition of the subsidy under the Agreement on Subsidies and Countervailing Measures (SCM Agreement) was an erga omnes obligation. ${ }^{54}$ Presumably, the Arbitrator meant erga omnes partes given that the obligations are binding only on WTO members. However, his reasoning does not support the suggestion that WTO obligations in general (or obligations arising from the SCM Agreement specifically) are erga omnes partes. He substantiated his finding by reference to the effects of the measure in question, rather than the obligation's nature and the treaty's object and purpose: 'once such a measure is in operation, its real world effects cannot be separated from the inherent uncertainty that is created by the very existence of such an export subsidy. ${ }^{55}$

Therefore, GATT obligations may be better classified as bilateralisable, while the rules on standing, as developed under the DSU, permit any WTO member to resort to the DSU in case of breach of a WTO obligation. ${ }^{56}$ This is fitting for international and regional energy markets given the factual interdependence of oil, gas, and electricity prices as well as of producers and consumers. Having examined WTO Agreement obligations that may apply to energy trade, the following section discusses the obligations under the ECT.

\subsection{The Energy Charter Treaty}

The ECT is the first sector-specific multilateral treaty governing numerous aspects of the energy sector: eg trade in Articles 5 and 29; transit in Article 7; protection of foreign investment in Part III; protection of the environment in Article 19 and

54 WTO, United States-Tax Treatment (n 48) para 6.10.

55 ibid para 6.8.

56 Tarcisio Gazzini, 'The Legal Nature of WTO Obligations and the Consequences of their Violation' (2006) 17 EJIL 723; Joost Pauwelyn, 'A Typology of Multilateral Treaty Obligations: Are WTO Obligations Bilateral or Collective in Nature?' (2003) 14 EJIL 907; Crawford (n 22) 451; Azaria (n 7) 126-130; In opposition, see Chios Carmody, 'WTO Obligations as Collective' (2006) 172 EJIL 419. Although the causes of action provided in GATT Article XXIII(1) include 'violations', 'non-violations', and 'other situations', only standing for breaches of the GATT have been examined here. 
competition in Article $6 .^{57}$ The ECT has 51 Contracting Parties, including the EU and Member States (with the exception of Italy, since 1 January 2016). ${ }^{58}$

The nature of ECT obligations has yet to be addressed in the publicly available ECT case law. The following sections examine some ECT obligations separately. They demonstrate that ECT obligations vary in terms of their nature. This difference in nature has implications for standing to invoke responsibility either by recourse to ECT dispute settlement procedures, or by recourse to countermeasures, where the latter are not excluded by lex specialis in the ECT. ${ }^{59}$

\subsubsection{Investment Protection Obligations}

The ECT investment obligations in Part III and the dispute settlement provisions of Article 26 apply solely in relation to investors bearing the nationality of an ECT Contracting Party in relation to an investment in the Area of another (host) ECT Contracting Party. They do not apply (by virtue of the ECT) to foreign investors who do not bear the nationality of an ECT Contracting Party. They also do not apply to investors that are nationals of an ECT Contracting Party in relation to investment made in the Area of that ECT Contracting Party. It could be argued that the manner in which the protection of investors of another Contracting Party is widened because the definition of 'investment' (ECT Article 1(6)(b)) requires the host Contracting Party to treat locally incorporated companies in conformity with ECT investment obligations, thus leading to the multilateralisation of the investment obligations. ${ }^{60}$ However, the purpose of such a provision is not to treat foreign and domestic investors in the same manner, with a view to protecting corporate entities per se; but to protect the interests of as many investors of each Contracting Party as possible. It could also be argued that the manner in which the most-favoured nation (MFN) treatment works in practice means that the investors of numerous Contracting Parties may be affected by a breach of the investment obligations and that this could mean that investment obligations should be considered erga omnes partes. ${ }^{61}$ However, the MFN treatment obligation is characterised by an exchange of

57

ibid.

Italy submitted a notification of withdrawal from the ECT to the Depository on 31 December 2014. Its withdrawal took effect on 1 January 2016, pursuant to ECT art 47(2).

Azaria (n 7) 173-84.

See also Stephen W Schill, The Multilateralization of International Investment Law (CUP 2010) 202.

See also Schill (n 60) 218-19. 
treatment, and reflects predominantly the individual interest of each Contracting Party to see its own nationals protected abroad, rather than a community interest that involves the protection of all commercial entities within a Contracting Party's jurisdiction.

Seen through these lenses, the ECT investment obligations rest on foreign nationality (that of another Contracting Party) and on a predominantly individual interest of each ECT Contracting Party to see their nationals protected abroad. They may be better classified as bilateralisable. ${ }^{62}$

\subsubsection{Trade and Transit Obligations}

There is no evidence that theECT trade and transit obligations are not bilateralisable. ${ }^{63}$ Given that trade and transit, as a general matter, are based on reciprocal exchanges between treaty parties (unless there is evidence to the contrary), it is arguable that they are owed in pairs between ECT Contracting Parties.

Incidents have come up where violations of ECT obligations concerning transit (Article 7) and exports (Article 29) have either occurred or the lawfulness of the measures taken by the transit and exporter/importer ECT Contracting Party could at least have been challenged. However, since on none of these occasions did Contracting Parties make any claims of 'relatively formal form' for the cessation of an internationally wrongful act, no concrete conclusions can be drawn from their practice as to the nature of the trade and transit obligations. ${ }^{64}$

Subsequent agreements between some ECT Contracting Parties provide evidence that priority is given to the ECT in the case of conflict between ECT provisions and the provisions of subsequent agreements. This practice of ECT Contracting Parties may support the view that the trade and transit provisions of the ECT are of integral nature. For instance, all Nabucco Agreement parties and TAP Treaty parties are ECT Contracting Parties. The Nabucco Agreement explicitly does not derogate from the ECT and the founding EU treaties ${ }^{65}$ and

62 Giorgio Gaja, 'The Concept of an Injured State' in James Crawford and others (eds), The Law of International Responsibility (OUP 2010) 944.

63 ECT (n 13) arts 5, 7, 29.

64 Azaria (n 7) 89-94: the 2004 Belarus-Russia gas export/transit dispute; the 2006 and 2009 Ukraine-Russia gas transit/export disputes; the 2007 Belarus-Russia oil transit/export dispute; the 2010 interruption of gas transit by Belarus.

Nabucco Agreement (n 38) art 3.1. 
the TAP Treaty is in furtherance of the ECT. ${ }^{66}$ All these provisions may indicate that parties do not intend to depart from their ECT obligations. However, it is unclear that they included such treaty provisions specifically owing to the erga omnes partes nature of the ECT trade and transit obligations. In light of the lack of evidence to the contrary, it is better to argue that ECT trade and transit obligations are bilateralisable.

\subsubsection{Environmental Obligations}

Article 19 on 'Environmental Aspects' sets out erga omnes partes obligations. ${ }^{67}$ Article 19 of the ECT comprises three paragraphs. ${ }^{68}$ Paragraph 1 consists of a chapeau, containing framework obligations, and a (non-exhaustive) list of obligations specifying the obligations in the chapeau. The chapeau establishes an obligation on Contracting Parties to 'strive to minimize in an economically efficient manner harmful Environmental Impacts occurring either within or outside its Area from all operations within the Energy Cycle in its Area. ${ }^{69}$ Unlike the Convention on the Law of the Sea (UNCLOS), where the term 'Area' defines a space beyond national jurisdiction, the term 'Area' in the ECT expressly means spaces within national jurisdiction. ${ }^{70}$ Additionally, contrary to customary international law, which only requires that states prevent significant transboundary harm, ${ }^{71}$ Article 19 deals with

TAP Treaty (n 39) Preamble.

ECT (n 13) art 19.

For an overview of ECT (n 13) art 19, see Clare Shine, 'Environmental Protection under the Energy Charter Treaty' in Thomas Walde (ed), The Energy Charter Treaty: An East-West Gateway for Investment and Trade (Kluwer Law International 1996) 520.

ECT (n 13) art 19(1). The wording 'shall strive' does not affect the normative character of the rule. The obligation is one of conduct, and the question is about the manner in which, and the time at which, such obligation is to be breached.

United Nations Convention on the Law of the Sea (adopted 10 December 1982, entered into force 16 November 1994) 1833 UNTS 3 (UNCLOS). Compare UNCLOS art 1(1) and ECT (n 13) art 1(10).

Patricia Birnie, Alan Boyle and Catherine Redgwell, International Law and the Environment (3rd edn, OUP 2009) 137, 167; In opposition, see Phillippe Sands and Jacqueline Peel with Adriana Fabra and Ruth MacKenzie, Principles of International Environmental Law (3rd edn, CUP 2012) 201; International case law has only found violations of the obligation not to cause (and subsequently to prevent) transboundary harm (or harm in the context of a shared resource), not of harm to the environment within one state's jurisdiction. See Trail Smelter Case (United States v Canada) (1941) 3 RIAA, 1965; Corfu Channel Case (UK v Albania) (Merits, Judgment) [1949] ICJ Rep 4; Legality of the Threat or Use of Nuclear Weapons (Advisory Opinion) [1996] 
any environmental harm occurring outside the jurisdiction of the Contracting Party where the harmful energy activity takes place, as well as with environmental harm occurring within the jurisdiction of the Contracting Party, in whose jurisdiction the harmful energy activity takes place. In the absence of a requirement connecting jurisdiction and harm, there is no evidence that the obligation in Article 19(1) is based on a bilateral relationship between Contracting Parties, whose environment would be affected by a harmful energy activity in another Contracting Party. Rather, the obligation protects a community interest-the environment per se. It is better classified as an obligation erga omnes partes.

\subsubsection{Dispute Settlement Provisions and Standing}

The ECT contains numerous dispute settlement mechanisms-a general interContracting Party arbitration mechanism in Article 27; an investor-Contracting Party arbitration provision in Article 26; a special transit conciliation procedure in Article 7(7); a special provision for the settlement of environmental disputes in Article 19(2) and a special procedure for settling trade disputes concerning Articles 5 and 29 in Annex D. Since none of these provisions contains detailed rules concerning standing, standing to resort to ECT dispute settlement depends on the nature of each obligation breached.

Given that the transit obligations under Article 7 are bilateralisable, only individually injured Contracting Parties can resort to conciliation or to general inter-Contracting Party dispute resolution. ${ }^{72}$ Similarly, as the investment obligations in Part III are bilateralisable, only individually injured Contracting Parties may resort to general inter-Contracting Party dispute settlement. ${ }^{73}$ Since trade obligations under Articles 5 and 29 are bilateralisable, standing to resort to Annex

ICJ Rep 226, 242 para 29; Pulp Mills on the River Uruguay (Argentina v Uruguay) (Judgment) [2010] ICJ Rep 14, para 101; Cf Iron Rhine 'IJZEREN RIJN' Railway (Belgium v Netherlands) (2005) 27 RIAA para 59. However, the relevant passage in the latter award could be interpreted as recognising an obligation to prevent environmental harm generally only by taking the tribunal's reasoning out of the dispute's context: the harm at issue would be caused by activities of one state (Belgium) taking place in the territory of another state (the Netherlands).

72 ECT (n 13) art 27.

73 Pursuant to ECT (n 13) art 27(2) the inter-Contracting Parties arbitral tribunal has jurisdiction over disputes concerning the application and interpretation of all provisions in Part III on Investment Promotion and Protection. However, art 27(2) expressly excludes from the tribunal's jurisdiction disputes concerning the application and interpretation of the last sentence of art 10(1) and only for Contracting Parties listed in Annex IA. 
D should be available only to individually injured Contracting Parties. However, although Annex D does not specifically provide for standing, it is arguable that, given the effort of the negotiating parties of the ECT to parallelise Annex D to the WTO DSU, Annex D may be interpreted as affording generous standing to all Contracting Parties. ${ }^{74}$ Finally, given that environmental obligations are erga omnes partes, any Contracting Party may resort to dispute resolution under Article 19(2).

\subsection{Bespoke Pipeline Treaties between EU Member States and Third States}

In the post-Cold War period, the trend to conclude bespoke pipeline treaties has been increasing. A number of reasons may have prompted this trend, but this question falls beyond the scope of this study. ${ }^{75}$ This treaty practice is by no means unique to Europe. Numerous such treaties have been concluded in relation to cross-border and transit pipelines in the Middle East, Central Asia, and Africa. ${ }^{76}$

However, the treaty practice involving EU Member States is of interest because of the context in which it is taking place. First, it can be seen as a reaction to the need to diversify routes and sources in the aftermath of the 2009 gas crisis that occurred in Europe owing to the gas transit and export dispute between Russia and Ukraine. Second, it will continue to be observed-if not to increase-as many of these projects are eligible for funding by the EU, when characterised as 'projects of common interest' under Decision No $1364 / 2006{ }^{77}$ or as 'priority corridors' under

74 No subsequent practice of Contracting Parties supports this interpretation as yet.

75 Azaria (n 7) 7, 58.

76 For instance, see Treaty on the West African Gas Pipeline Project between Benin, Ghana, Nigeria, and Togo (31 January 2003) <http://www.wagpa.org/Treaty_on_WAGP_Project.pdf> accessed 28 September 2016; Agreement among Azerbaijan, Georgia and Turkey Relating to the Transportation of Petroleum via the Territories of Azerbaijan, Georgia and Turkey Through Baku-Tbilisi-Ceyhan Main Export Pipeline (signed 18 November 1999, entered into force 9 October 2000) <http://subsites.bp.com/caspian/BTC/Eng/agmt4/agmt4.pdf> accessed 28 September 2016; Agreement between Kazakhstan and China on cooperation in the construction and operation of gas pipeline Kazakhstan-China (signed 18 August 2007), Kazakhstan OJ No 218-IV; Agreement between Qatar and the United Arab Emirates Relating to the Transmission of Gas by Pipeline Between Qatar and the United Arab Emirates (signed 26 September 2004, entered into force 9 July 2005) <http://www.almeezan.qa/AgreementsPage. aspx?id=1483\&language $=$ en $>$ accessed 28 September 2016.

77 Decision No 1364/2006/EC [2006] OJ L262/1 of the European Parliament and of the Council of 6 September 2006 laying down guidelines for trans-European energy networks and repealing Decision 96/391/EC and Decision No 1229/2003/EC. 
Regulation $347 / 2013,{ }^{78}$ with a view to reinforcing the security of energy supplies by strengthening relations with third countries. ${ }^{79}$ Third, the compatibility with EU law, especially competition law and the internal energy market legislation, of the treaties and other arrangements for these projects has been a matter of concern for the European Commission. ${ }^{80}$ From the point of view of public international law, EU Member States may conclude treaties with third states, but they remain obliged to comply with their existing EU law obligations. If there is an incompatibility between treaty provisions with third parties and EU law provisions, the treaty with the third states will be the applicable legal standard between them and the third state, while the applicable legal standard in their relationship with EU Member States will be EU law. ${ }^{81}$ EU Member States will incur responsibility for the breach of EU law obligations. ${ }^{82}$ A possible solution may be to withdraw from the treaties with a third state, which can take place either in accordance with the relevant provisions of these treaties or in the absence of such provisions, by reference to extraneous grounds under custom or the VCLT, where applicable $;^{83}$ or to pursue the amendment of these treaties with a view to ensuring compatibility with EU law. ${ }^{84}$ However, both choices are politically and procedurally cumbersome. For states that became EU Member States after the conclusion of treaties with third

Regulation (EU) No 347/2013 [2013] OJ L115/39 of the European Parliament and of the Council of 17 April 2013 on guidelines for trans-European energy infrastructure and repealing Decision No 1364/2006/EC and amending Regulations (EC) No 713/2009, (EC) No 714/2009 and (EC) No 715/2009. This Regulation includes a list of 'priority corridors' that are eligible for EU financial aid (art 6(3)).

79 The Nabucco Pipeline was listed in Annex III of Decision No 1364/2006/EC (n 77) as a project of common interest, and was eligible for EU financial aid (art 6(3)); Regulation (EU) No 347/2013 (n 78) included a list of priority corridors that include all EU Member States in whose territory the Nabucco pipeline would be constructed; the Trans-Adriatic Pipeline has been listed since 2006 in Annex III of Decision 1364/2006/EC (n 77) as a project of common interest and is eligible for EU financial aid (art 6(3) and s 9.25, Annex III).

80 European Commission, 'Proposal for a Decision of the European Parliament and of the Council on establishing an information exchange mechanism with regard to intergovernmental agreements and non-binding instruments between Member States and third countries in the field of energy and repealing Decision No 994/2012/EU COM (2016) 53 final (Commission's Proposal for Regulation repealing Decision No 994) para 4.

81 VCLT (n 34) art 30(4)(b).

82 ibid art 30(5).

83 None of the grounds for termination under the VCLT and custom permit termination on the ground that one or more of the treaty parties are obliged to comply with other conflicting international obligations. 
states that are incompatible with EU law (eg Croatia concluded a bilateral treaty with Russia concerning the South Stream pipeline prior to its accession to the EU), TFEU Article 351 provides that the TFEU does not affect such treaties. ${ }^{85}$ However, to the extent that they are incompatible with the TFEU, the Member States(s) are obliged to 'take all appropriate steps to eliminate the incompatibilities established. ${ }^{86}$ EU Member States are thus obliged under EU law either to amend treaties with third states or to withdraw from them.

Fourth, in February 2016, the European Commission proposed amending Decision No 994/2012. ${ }^{87}$ Under the proposed amendment, EU Member States would be obliged to abstain from expressing consent to be bound by treaties with third states in the energy sector (including bespoke pipeline treaties) before the European Commission has made an assessment as to the compatibility of such treaties with EU law. Member States would also be obliged to 'take (into) utmost account' the European Commission's assessment when concluding the negotiation of such treaties. ${ }^{88}$ Fifth, existing EU law and the proposal of the Commission to amend existing EU law favours multilateral treaties with third states. This express preference implies that the Commission may not favour bilateral energy-related treaties. $^{89}$

Against this background, it is valuable to examine bespoke pipeline treaties between EU Member States and third states: two plurilateral treaties (the Nabucco Agreement and the TAP Treaty), and the bilateral treaties for the South Stream pipeline. The term 'plurilateral bespoke pipeline treaties' is to be contrasted with 'bilateral bespoke pipeline treaties', and with 'multilateral treaties' (eg the WTO Agreement and the ECT), ${ }^{90}$ which are not tailor-made for a particular pipeline. The

TFEU (n 3) art 351; Case 812/79 Attorney General v Juan C Burgoa [1980] ECR 2787, para 8; Case C-84/98 Commission v Portugal [2000] ECR I-5215, para 53; For an overview of TFEU art 351, see Piet Eeckhout, EU External Relations Law (OUP 2011) 396-436.

TFEU (n 3) art 351; where necessary, the Member States must assist each other with a view to eliminating the incompatibilities established and must adopt, where appropriate, a common attitude. '[T]he Commission (...) may facilitate mutual assistance between the Member States concerned and their adoption of a common attitude. Case C-205/06 Commission v Republic of Austria [2009] ECR I-1301, para 44.

87 Decision No 994/2012/EU [2012] OJ L299/13 of the European Parliament and of the Council of 25 October 2012 establishing an information exchange mechanism with regard to intergovernmental agreements between Member States and third countries in the field of energy.

88 Commission's Proposal for Regulation Repealing Decision No 994 (n 80) art 5(4).

89 ibid art 9(d); Decision No 994/2012/EU (n 87) art 7.

90 WTO Agreement (n 13); ECT (n 13). 
use of the term 'plurilateral' here is only descriptive of the treaties' form (which is multilateral) and does not entail legal consequences under the law of treaties in relation to the topic discussed here. Each treaty and each treaty obligation has to be interpreted separately. The following analysis focuses on obligations concerning uninterrupted energy flows via the pipelines.

\subsubsection{Plurilateral Bespoke Pipeline Treaties}

The Nabucco Agreement requires treaty parties 'not to permit or require the Interruption of gas transportation in the Nabucco (pipeline). ${ }^{, 91}$ The treaty's object and purpose is to ensure the 'security of supply (since) this is necessary for the welfare and security of each citizen and (...) States Parties are therefore determined to act in a spirit of solidarity to achieve collective energy security. ${ }^{.92}$ The TAP Treaty requires parties not to interrupt flows of gas through the pipeline. ${ }^{93}$ The Preamble of the Treaty states that the Treaty forms part of an effort to promote cooperation in ensuring the reliable supply of gas from states in Central Asia to the EU, none of which is party to the Treaty, and 'to create uniform (...) conditions and standards for the (...) construction, and operation of (the Pipeline) ${ }^{, 94}$ Additionally, the Treaty categorically prohibits unilateral denunciations and inter se modifications. ${ }^{95}$

The obligations not to interrupt transportation of energy via an integral pipeline system, which crosses the territory of numerous states, could be classified as 'interdependent obligations'. What connects interdependent obligations is their negative nature: they require states, for instance, not to acquire arms or not to acquire nuclear weapons. As in relation to interdependent obligations, parties to bespoke pipeline treaties have a strong interest in cessation of the international wrongful act pertaining to the interruption of energy carriage, restitution and assurances of non-repetition rather than in compensation. Their interest is to guarantee the 'regime' by re-establishing energy flows. Owing to these features, this could be seen as the natural classification of obligations concerning energy transportation via pipelines in the context of multilateral bespoke pipeline treaties unless there is evidence to the contrary, which is the case for the Nabucco Agreement and the TAP 
Treaty. The features of the Nabucco Agreement and the TAP Treaty demonstrated above support the proposition that the obligations concerning uninterrupted energy flows therein are erga omnes partes. They are established primarily for a common interest (collective energy security), including a wider common interest of states beyond the treaty parties, and they are intended to set uniform standards for a regional project.

This section has shown that two plurilateral bespoke pipeline treaties that EU Member States have concluded with third states establish obligations erga omnes partes and thus all treaty parties have standing to invoke responsibility (although it is questionable whether those other than the injured state may resort to countermeasures). ${ }^{96}$ The following section touches on the bilateral treaties that EU Member States and third states in the Balkan region have concluded with Russia concerning the South Stream pipeline.

\subsubsection{Bilateral Bespoke Pipeline Treaties}

In addition to multilateral treaties governing the construction and operation of one physically indivisible pipeline that crosses the territory of numerous states, the practice of states also reveals compounds of bilateral treaties concluded for such projects. A paradigmatic example of European interest is the bilateral treaties concluded between Russia, a gas exporting state, on the one hand, and each transit and importing state for the South Stream pipeline on the other hand, some of which are EU Member States. ${ }^{97}$ These include provisions concerning the construction and operation of the pipeline, including an obligation not to interrupt energy carriage.

Owing to the vehicle used to establish such obligations (bilateral treaties), the obligations under each treaty are bilateral and are owed between the parties to them. There is no evidence in the treaties that EU Member States have concluded with Russia or in the circumstances of their conclusion that there is an intention to establish rights (eg concerning uninterrupted transportation) for third states through whose territory the pipeline will be constructed or for a wider group of states. ${ }^{98}$

97 See (n 40). For compatibility of the provisions in these treaties with EU law provisions, see analysis in section 2.3 above. 


\subsection{Interim Conclusions}

Within the ambit of international energy law, community interest obligations appear in the treaty practice of Member States (eg obligations in bespoke pipeline treaties with third states, such as the Nabucco Agreement and the TAP Treaty) and in some multilateral treaties to which the EU is itself a party (eg ECT environmental obligations). However, the EU and Member States have also undertaken bilateral or bilateralisable obligations in the energy sector. WTO obligations apply to energy trade and are bilateralisable; but generous standing has been afforded to all WTO members to invoke responsibility for breaches of WTO obligations under the DSU. The ECT contains some bilateralisable obligations, such as those concerning trade, transit and investment. Furthermore, EU Member States conclude bilateral treaties with third states in the energy sector (eg with Russia for the South Stream pipeline). This section has explained that community interest obligations appear along with bilateral and bilateralisable obligations within the scope of international energy law that are of particular interest for the EU and Member States, and how this determines standing to implement the responsibility for a breach of these obligations. The following section examines whether lawful countermeasures, as a means of implementing international responsibility, can take the form of suspending compliance with energy-related obligations.

\section{Suspending Compliance with Community Interest Obligations in International Energy Law}

This section examines energy-related countermeasures. Countermeasures are a means of implementing international responsibility. ${ }^{99}$ They involve the suspension of compliance with an international obligation, but because they are taken in response to a previously internationally wrongful act, countermeasures are one of the circumstances that preclude wrongfulness. ${ }^{100}$ The following analysis assesses whether, and if so how, the community interest nature of obligations plays a role in determining the lawfulness of a countermeasure in the form of suspending compliance with treaty obligations relating to the energy sector. This analysis is important because resorting to energy-related countermeasures may be preferred 
among the available responses to wrongfulness in the UN era, given their significant effects on the responsible state and their corresponding persuasiveness.

Section 3.1 examines whether countermeasures in the form of suspending compliance with treaty obligations in the energy sector are unavailable. Section 3.2 examines whether countermeasures in the form of suspending compliance with obligations in the energy sector may not meet the conditions of lawfulness of countermeasures to the extent that the latter take into account community interest obligations.

\subsection{Displacing Countermeasures as Circumstances Precluding Wrongfulness}

The argument that countermeasures as circumstances precluding wrongfulness may be displaced by lex specialis is founded on two separate bases-treaty language that displaces countermeasures, as circumstances precluding wrongfulness; and the nature of the obligations whose performance is to be suspended implicitly displaces countermeasures. First, some treaties concerning energy trade and investment contain security exceptions-for instance, GATT Article XXI and ECT Article 24. The relationship between security exceptions and circumstances precluding wrongfulness under the law of state responsibility has been the focus of a series of investor-state arbitrations against Argentina on the basis of bilateral investment treaties to which Argentina is party. While a number of arbitral tribunals have dealt with this issue differently, ${ }^{101}$ the more persuasive position is that when the language used in a security exception is (or resembles substantially) 'nothing shall prevent the parties from', as is the language used in GATT Article XXI and ECT Article 24, such language suggests that the exception delineates the scope of primary treaty obligations. Conduct within the scope of the exceptions is not in breach of the treaty obligations. In contrast, circumstances precluding wrongfulness are part of secondary rules and preclude the wrongfulness of a conduct that would otherwise be wrongful: meaning conduct that would not fall within the scope of

101 Treaty exceptions are lex specialis and supersede the customary circumstances precluding wrongfulness: LG\&E $v$ Argentine Republic (Decision on Liability) (ICSID Case No ARB/02/1) 3 October 2006, paras 245-61; Patrick Mitchell v Democratic Republic of the Congo (Decision on the Application for Annulment of the Award) (ICSID Case No ARB/99/7) 1 November 2006, para 55; interpreting treaty exceptions through VCLT (n 33) art 31(3)(c) to incorporate conditions from secondary rules under custom: CMS Gas Transmission Company v Argentine Republic (Award of the Tribunal) (ICSID Case No ARB/01/8) 12 May 2005, paras 315-82. 
such security exceptions. ${ }^{102}$ This was also the reasoning of the PCIJ in the Railway Traffic Advisory Opinion (1931). ${ }^{103}$

Most bespoke pipeline treaties do not contain security exception provisions, as is the case of those examined here. However, some contain other language that may displace countermeasures, as circumstances precluding wrongfulness. The TAP Treaty permits non-performance of treaty obligations only by prior consent of all parties. This rule is located in a provision that deals with the treaty's operation that is separate from the provisions requiring states not to interrupt energy flows. ${ }^{104}$ The argument could be made that this treaty provision displaces countermeasures under the law of international responsibility taken in this particular form (meaning in the form of interrupting energy flows). The provision overlaps with countermeasures in that they both relate to suspension of performance of obligations, but it deviates from countermeasures, which are unilateral and are not premised on prior consent by the responsible state or any other state. Such interpretation would entail the displacement of any unilaterally operational circumstance precluding wrongfulness.

Second, as a separate argument, the community interest nature of some obligations of international energy law could be seen as entailing ipso facto nonsusceptibility to unilateral countermeasures. In his work on state responsibility, ILC Special Rapporteur Arangio-Ruiz suggested that, owing to their indivisible nature, erga omnes partes obligations may not be susceptible to countermeasures. ${ }^{105}$ However, his proposal was not taken up by the ILC-it was rather changed into a clause that severs the preclusion of wrongfulness towards the responsible state from the nonpreclusion of wrongfulness towards the non-responsible affected states. ${ }^{106}$ The approach of the ASR in relation to this issue may cast some doubt on the argument that countermeasures in the form of suspending performance of erga omnes partes obligations are displaced owing to the indivisible nature of such obligations.

102 ILC (n 15) 7; CMS Gas Transmission Company v Argentine Republic (Decision of the ad hoc Committee on the Application for Annulment of the Argentine Republic) (ICSID Case No ARB/01/8) 25 September 2007, paras 129-35; Sempra Energy International v Argentine Republic (Ad hoc Committee, Decision on the Argentine Republic's Request for Annulment of the Award) (ICSID Case No ARB/02/16) 29 June 2010, paras 200-04.

103 Railway Traffic between Lithuania and Poland (Railway Sector Landwarów-Kaisiadorys) (Advisory Opinion) PCIJ Rep Series A/B, No 39, 107.

104 TAP Treaty (n 39) art 12.

105 Special Rapporteur Arangio-Ruiz, 'Fourth Report on State Responsibility' (1992) II ILCYB; UN Doc A/CN.4/SER.A/1992/Add.1 (Part 1) paras 92-93.

106 ILC (n 15) 130 and art 49. 
The following section examines whether suspending performance of energyrelated obligations meets the conditions of lawfulness of countermeasures under custom, assuming that countermeasures are not displaced by lex specialis.

\subsection{Conditions of Lawfulness of Countermeasures under Customary International Law}

Countermeasures, in order to be lawful, have to meet a number of conditions under customary international law. ${ }^{107}$ One of these conditions is that a countermeasure has to be targeted against the responsible state. ${ }^{108}$ This condition-according to the ILC-is based on the 'relative preclusion of wrongfulness. ${ }^{109}$ The wrongfulness of the countermeasure is precluded vis-à-vis the responsible state, but not vis-àvis a third non-responsible state. For instance, if Ukraine suspends compliance with transit obligations that it owes to Russia as a countermeasure for the latter's internationally wrongful act, while at the same time it owes a transit obligation to the EU and/or Member States (eg GATT Article V or ECT Article 7), the wrongfulness of interrupting transit vis-à-vis Russia may be precluded, but it will not be precluded vis-à-vis the EU and Member States simply owing to Russia's wrongful conduct. In such situations, reacting states are faced with a dilemma. They may respond against the responsible state, but they will have to make reparations to third (not responsible) states; or they may abstain from resorting to countermeasures against the responsible state (at least in this particular form), owing to the burden of having to make reparations to third states.

On the other hand, other conditions of lawfulness of countermeasures may be attuned to the community interest nature of international obligations. Some reflect the need to protect community interests per se; others may coincidentally allow the consideration of the community interest nature of a primary obligation when assessing the lawfulness of a countermeasure. Two conditions of the lawfulness of countermeasures are discussed in the following sequence-that countermeasures shall not affect fundamental human rights obligations and that they have to be proportionate to the injury suffered. ${ }^{110}$

109 ibid 130.

110 ibid arts 50-51. 


\subsubsection{Prohibition of an Effect on Fundamental Human Rights Obligations}

If individuals are deprived of sufficient heating, water, sanitation and medical assistance or the use of medical equipment in hospitals or at home due to interruptions to the supply of electricity, oil and gas, there may be loss of life, or individuals may be subject to degrading treatment or their health may be put at risk. This is far from an academic discussion. During the 2009 gas crisis in Europe, deaths were reported in Poland and Bulgaria. ${ }^{111}$

The rule that countermeasures shall not 'affect obligations for the protection of fundamental human rights ${ }^{112}$ covers two situations: where the state resorting to the countermeasure suspends compliance with its human rights obligations per se; and where the state resorting to the countermeasure suspends compliance with other international obligations and in so doing affects its human rights obligations. It is this second situation that relates to countermeasures in the form of energytrade restrictions.

However, this prohibition faces numerous limitations. The following analysis touches on two of these limitations: ${ }^{113}$ the extraterritorial application of human rights obligations, and the effect on human rights.

\subsubsection{Extraterritorial Application of Human Rights}

Human rights obligations apply within the territory of the state resorting to countermeasures ('reacting state'), and extraterritorially, where the reacting state exercises control. Unlike situations where state organs are present in areas outside the state's territory and exercise control over a particular area ${ }^{114}$ or over a

111 Bilefsky and Kramer (n 7).

112 ILC (n 15) art 50.

113 Another limitation is that ASR art 50 (n 15) refers to 'fundamental human rights', which implies a smaller group of obligations within human rights generally. The term cannot mean only human rights that are found in jus cogens norms; such requirement would be superfluous, since the requirement that countermeasures do not affect obligations jus cogens is a separate condition for lawfulness (ASR art $50(1)(d)$ ); the term 'fundamental human rights' was proposed by Rapporteur Arangio-Ruiz based on the distinction adopted at the time between 'core' or 'basic' human rights and 'other' human rights. Special Rapporteur Arangio-Ruiz (n 105) para 80; For further analysis: Azaria (n 7) 234-36.

114 Loizidou $v$ Turkey (Preliminary Objections) (1995) Series A no 310, para 62; In relation to full and exclusive control over a prison or a ship respectively, see Al-Saadoon and Mufdhi $v$ United Kingdom App No 61498/08 (ECtHR, 30 June 2009) paras 86-89; Medvedyev and others v France App No 3394/03 (ECtHR, 20 March 2010) para 67. 
particular individual, ${ }^{115}$ interrupting energy exports or transit involves conduct in the territory of the reacting state that produces effects on individuals located in the territory of the responsible state ('targeted state').

The case law of the European Court of Human Rights (ECtHR) concerning territorial conduct, which has extraterritorial effects, is limited. However, the ECtHR has considered that individuals fall within the 'jurisdiction' of a state within the meaning of Article 1 of the European Convention on Human Rights (ECHR), ${ }^{116}$ in circumstances where its organs are located within its own territory (or where the state exercises effective control) but are in close vicinity to the victims that are located in another state and there is a direct and immediate causal link between their conduct and the effect on the individual concerned. ${ }^{117}$

Interruptions of energy exports or transit may in certain circumstances fulfill the vicinity and the causation link criteria, for instance, where the importing state is wholly dependent on established energy flows from the exporter or the transit route. Such instances include Belarus' dependence on Russia's exports of gas, and the dependence of Moldova on gas transiting through Ukraine and gas exports from Russia. ${ }^{118}$ However, the case law where such a threshold has been established is confined to obligations to abstain from interfering with the enjoyment of rights. ${ }^{119}$ States are obliged not to kill, not to subject individuals to degrading treatment, and not to put at risk the health of individuals that are located in the territory of another state. By contrast, it is doubtful that obligations to take positive measures

115 Öcalan v Turkey App No 46221/99 (ECtHR, 12 May 2005) para 91.

116 Convention for the Protection of Human Rights and Fundamental Freedoms (adopted 4 November 1950, entered into force 3 September 1953, amended by Protocols Nos 3, 5, 8 and 11) 213 UNTS 222 (ECHR).

117 Andreou $v$ Turkey App no $45653 / 99$ (ECtHR, 3 June 2008), section A.3(c); Additional support for the Court's reasoning in this respect can be drawn from Nada $v$ Switzerland App no 10593/08 (ECtHR, 12 September 2012). The claimant resided in an Italian enclave surrounded by Switzerland. The ECtHR presumed that the individual fell within Switzerland's 'jurisdiction' without giving reasons (para 122). It found that, by prohibiting the claimant from entering or transiting through its territory, Switzerland violated his right to private life. Neither Switzerland nor any intervening state objected on the grounds that Nada was outside Switzerland's 'jurisdiction'. The exceptional situation, which involved an enclave of 1.6 square kilometres of Italian territory, where the claimant resided, may have prompted the Court's reasoning, but Switzerland's conduct was conduct that took place within its own territory albeit that it produced extraterritorial effects.

118 See $\mathrm{n} 8$.

119 Andreou $v$ Turkey App no $45653 / 99$ (ECtHR, 3 June 2008); Nada $v$ Switzerland App no 10593/08 (ECtHR, 12 September 2012). 
to protect the right to life, freedom from degrading treatment or the right to health by providing energy apply in such an extraterritorial manner. No case law or state practice as yet supports (albeit it does not preclude) the view that obligations to take positive measures to protect human rights apply in such manner. ${ }^{120}$

\subsubsection{2 'Effect' on Human Rights Obligations}

Even assuming arguendo that the 'jurisdiction' threshold was to be fulfilled, ${ }^{121}$ it would have to be proven that the effect on the human rights of individuals in the targeted state is the result of the countermeasure. Such a link depends on the facts, and may not be easily identified. Furthermore, the reacting state may argue against the existence of such a link because the targeted state has not taken the necessary measures to protect the human rights of individuals within its own territory. For example, the reacting state could have mitigated the effects of an energy crisis by taking pre-emptive or other measures such as storage or entering into energy sharing mechanisms like the International Energy Agency mechanism of oil stockpiling and demand restraints or the EU Gas Security mechanism. ${ }^{122}$ Hence, in the current state of international law, the rule that countermeasures cannot affect human rights obligations is unlikely to result in countermeasures in the form of interrupting energy flows being unlawful.

\subsubsection{Proportionality}

Under customary international law, countermeasures have to be proportionate to the injury suffered, taking into account the rights in question. ${ }^{123}$ The following sections explain how the condition of proportionality of countermeasures accommodates community interest obligations. First, the effects on human rights

120 For counterarguments that may support the extraterritorial application of obligations and the conduct discussed here, see Azaria (n 7) 243-44.

121 As a separate matter, there is no evidence that a stricter jurisdictional link is required for the customary right to life and freedom from inhuman treatment, or the right to health (assuming that it attains customary status) other than the one applicable to human rights treaties.

122 Agreement on an International Energy Program (concluded 18 November 1974, entered into force 19 January 1976) 1040 UNTS 271, arts 2-3; Council and Parliament Regulation (EU) 994/2010 (n 9).

123 ILC (n 15) art 51; Gabčvkovo-Nagymaros Project (Hungary/Slovakia) [1997] ICJ Rep 7, para 85. 
obligations of the targeted state will be discussed, and second, how the condition of proportionality takes into account the community interest nature of obligations whose performance is suspended as a countermeasure. In relation to the former issue, the question as to the existence of a human right to energy will be touched on. The analysis is put in the context of treaties to which all EU Member States are party (as at 28 September 2016): the ECHR and the European Social Charter (ESC). ${ }^{124}$

\subsubsection{Effects on Human Rights Obligations of the Targeted State: A Human Right to Energy?}

Countermeasures in the form of suspending compliance with exports or transit of energy can affect the ability of the targeted state to perform its own human rights obligations vis-à-vis individuals within its own territory. These include obligations to respect human rights by abstention and obligations to protect human rights by positive action. A countermeasure that has such an effect is likely to be disproportionate to the injury suffered, taking into account the rights in question. Since this criterion covers the rights of the injured and responsible states, ${ }^{125}$ the argument can be made that it also covers the ability of the targeted state to comply with its human rights obligations.

It is in this context that the question arises as to whether there is a 'human right to energy'. There is no human rights treaty specifically establishing the right to energy, or referring to energy in connection with the rights established in the treaty. ${ }^{126}$ However, the interpretation of existing treaties may establish obligations not to arbitrarily deprive access to energy in relation to vulnerable individuals (especially those dependent on the state) and especially in cases where such deprivation has no connection to the conduct of the individuals in question (eg non-payment of utility bills). Such an argument can also be made in relation to customary human rights law, where available.

124 European Social Charter (adopted 18 October 1961, entered into force 26 February 1965) 529 UNTS 89.

125 ILC (n 15) 135.

126 The only exception is Article 14(2) of the Convention on the Elimination of Discrimination against Women (adopted 19 December 1979, entered into force 3 September 1981) 1249 UNTS 13. The Article obliges parties to take all appropriate measures to eliminate discrimination against women in rural areas and, in particular, to ensure their right to enjoy adequate living conditions, particularly in relation to electricity. This provision is limited in scope of beneficiaries ('women in rural areas') and purpose ('elimination of discrimination'). 
Access to energy (oil, gas or electricity) is central for heating, cooking, use of medical equipment at home and hospitals, and for ensuring access to water, including for the purposes of sanitation. In light of this, it may be argued that when states arbitrarily deprive individuals of access to energy they may violate their obligation not to employ degrading treatment, their obligation to protect the right to life, their obligation to respect individuals' right to health, and the right to housing under human rights treaties (and customary international law, where available), such as the ECHR and the ESC.

The question has far-reaching implications for states-would such a right include only access to electricity or also gas and oil; or does it require states to provide uninterrupted energy or ensure the uninterrupted provision of energy by private entities (in cases other than non-payment of utility bills), and under which conditions (for free, on payment and if so, what would be the charges)? These issues fall beyond the scope of this study which examines a different issueaccess to energy in situations where individuals already have access to energy, and where provision of energy is interrupted for reasons that do not have to do with the human right-holder.

In relation to degrading treatment, in 1991, the European Commission on Human Rights rejected the admissibility of a complaint which argued that Belgium violated ECHR Article 3 because 'in the case at issue, the cutting off or the threat of cutting off electricity did not reach the level of humiliation or debasement needed for there to be inhuman or degrading treatment. ${ }^{127}$ This decision does not rule out the possibility that interfering with access to electricity may meet the threshold of treatment that would be inhuman or degrading. However, the decision did not provide detailed reasoning. Subsequent case law of the ECtHR has taken into account a number of the conditions present in the case of the applicant in this case, when it has accepted that a breach of ECHR Article 3 has taken place. The conditions that the European Commission on Human Rights could have considered include the applicant's economic conditions, her mental and physical state (she suffered from depression and respiratory problems), the duration of the lack of electricity and the weather conditions during which it took place, and the fact that the facilities in her residence allowed for no alternative energy sources. ${ }^{128}$

127 Francine van Volsem v Belgium App No 14641/89 (Commission Decision, 9 May 1990) 3 (emphasis added).

128 Antonio Cassese, 'Can the Notion of Inhuman and Degrading Treatment Be Applied to SocioEconomic Conditions?' (1991) 2 EJIL 141, 141-45. 
Additionally, subsequent ECtHR case law has clarified that the 'absence of (...) a purpose (to humiliate) cannot conclusively rule out a finding of a violation of Article 3. ${ }^{129}$ Moreover, a breach of Article 3 may occur 'in circumstances (where the individual is) wholly dependent on State support, (and is) faced with official indifference when in a situation of serious deprivation or incompatible with human dignity. ${ }^{130}$ Interruption of access to energy for heating, sanitation, light, cooking or the use of essential medical equipment to individuals dependent on the state may amount to a violation of their right to be free from degrading treatment under ECHR Article 3. They may also amount to a breach of the right to health, as part of the right to private life. ${ }^{131}$ Moreover, in relation to the ESC, the European Committee of Social Rights has recognised in its long-standing case law that the right to adequate housing under ESC Article 31(1) includes a dwelling with 'all basic amenities such as water, heating (...) and electricity (...). ${ }^{132}$ In relation to vulnerable individuals dependent on the state, interruption of energy for heating, sanitation, and cooking and medical support may constitute degrading treatment, a breach of the right to health, or a breach of the right to adequate housing.

To some extent, EU secondary legislation (incidentally) is compatible with the obligations of EU Member States under the ECHR: Article 3(3) of Directive 2009/73/EC concerning common rules for the internal market in natural gas requires EU Member States to:

take appropriate measures to protect final customers, [and] in particular, [to] ensure that there are adequate safeguards to protect vulnerable customers. [E] ach Member State shall define the concept of vulnerable customers which may refer to energy poverty and, inter alia, to the prohibition of disconnection of gas to such customers in critical times. ${ }^{133}$

129 Valašinas v Lithuania App No 44558/98 (ECtHR, 24 July 2001) para 101.

130 MSS v Belgium and Greece App No 30696/09 (ECtHR, 21 January 2011) para 253.

131 ECHR (n 116) art 8; Nada v Switzerland (n 117) para 151; Glor v Switzerland App No 13444/04 (ECtHR, 30 April 2009) para 54.

132 Centre on Housing Rights and Evictions (COHRE) v Italy, Complaint No 58/2009 (ECSR, 25 June 2010) para 54.

133 Directive 2009/73/EC of the European Parliament and of the Council of 13 July 2009 concerning common rules for the internal market in natural gas and repealing Directive 2003/55/EC [2009] OJ L211/94; In relation to electricity, see similar provisions in Article 3, Directive 2009/72/EC of the European Parliament and of the Council of 13 July 2009 concerning common rules for the internal market in electricity and repealing Directive 2003/54/EC [2009] OJ L211/55. 
However, the ECHR (and other international obligations of EU Member States) may require further measures vis-à-vis vulnerable individuals, and the protection of a wider group of individuals than those protected by Directive 2009/73. ${ }^{134}$

In extreme situations, where the targeted state is placed in a position where it cannot comply with its negative and positive obligations concerning the right to life, the right to be free from degrading treatment, and the right to health, ${ }^{135}$ owing to an interruption of energy exports or transit by a reacting state, such countermeasure would be disproportionate.

\subsubsection{In Relation to Targeting Community Interest Obligations}

As a separate matter, targeting community interest obligations may not meet the condition of proportionality. The reasoning of the ICJ in Gabčvkovo-Nagymaros supports this interpretation. Hungary had violated a bilateral treaty with Slovakia, which required both States to construct works for energy development on a part of the River Danube crossing the two States. Slovakia unilaterally responded by diverting a part of the river and by constructing alternative works along the course of the diversion. Slovakia claimed that its conduct was a lawful countermeasure against Hungary's prior breach. The ICJ found that ' $[t]$ he effects of a countermeasure must be commensurate with the injury suffered, taking account of the rights in question. $^{\text {,136 }}$

The Court did not explain the criteria by which it assessed proportionality. It could be argued that the Court's criterion was the aim pursued by Slovakia when resorting to the alleged countermeasure. Factually, Slovakia's measures meant that the adverse effects of Hungary's conduct were wiped out and Slovakia managed to

134 First, the term 'vulnerable customers' within Directive 2009/73 (and Directive 2009/72 concerning electricity) is to be determined by each EU Member State and, in any event, it does not necessarily coincide with the definition of vulnerable individuals as referred to in the case law of the ECtHR. Second, Directives 2009/73 and 2009/72 seem to require that disconnection from gas or electricity respectively cannot take place, but there is no equivalent obligation under EU law concerning oil.

135 The right to life and the right to be free from degrading treatment would qualify as 'fundamental human rights' within the meaning of the ASR. See ILC (n 15) art 50(1)(b); Special Rapporteur Arangio-Ruiz (n 105) paras 80-83; Given the close connection between the right to health and the right to life and freedom from degrading treatment, it may be argued that the right to health is also covered by the term 'fundamental human rights'; See also Azaria (n 7) 236.

136 Gabčvkovo-Nagymaros Project (Hungary/Slovakia) [1997] ICJ Rep 7, para 85. 
enjoy unilaterally the benefits it would have enjoyed had Hungary performed its treaty obligations. ${ }^{137}$ Thus, the measure's aim was not to induce Hungary to comply with its obligations but rather an attempt to benefit from non-compliance.

Although this interpretation is defensible, especially in light of the facts, the Court's reasoning in paragraph 85 of the Judgment allows for a different interpretation. The ICJ alluded to the findings of the PCIJ in River Oder concerning the creation of a 'community of interest on a navigable river [which] becomes the basis for a common legal right' (of navigation) of riparian states on international rivers. ${ }^{138}$ Although it did not specifically link the community interest nature of those obligations to the assessment of the lawfulness of the countermeasure in question, it made an analogy between the common legal right of navigation and the modern developments of international law concerning non-navigational uses of international watercourses. This reasoning allows for the argument that the community interest and hence indivisible nature of the obligation whose performance is being suspended as a countermeasure may be a qualitative criterion for measuring proportionality. ${ }^{139}$ For instance, given that the obligations concerning the protection of the environment in ECT Article 19 and the obligations concerning uninterrupted energy flows under the Nabucco Agreement and the TAP Treaty are erga omnes partes, suspending their performance would not constitute a lawful countermeasure because it would not meet the condition of proportionality.

\section{Conclusion}

Reciprocity and the making of bilateral or bilateralisable obligations dominate international rules concerning the energy sector. While multilateral treaties that apply to energy trade (eg WTO Agreement) or specific to the energy sector (eg ECT) have been concluded since the end of the Cold War, the rise of multilateralism has not necessarily brought about community interest obligations in this field. For instance, GATT obligations and ECT obligations concerning trade and investment are bilateralisable.

137 Enzo Cannizzaro, 'The Role of Proportionality in the Law of International Countermeasures' (2001) 12 EJIL 889, 898-99.

138 Case Relating to the Territorial Jurisdiction of the International Commission of the River Oder (Judgment) PCIJ Rep Series A No 23, 5.

139 According to the ILC, the criteria for proportionality in the framework of the ASR are quantitative and qualitative. ILC (n 15) 134-35. 
However, to suggest that this is the whole picture would be misleading. The EU founding treaties and, by implication, the secondary sectoral legislation on energy do not establish reciprocal undertakings between EU Member States according to Van Gend Loos. ${ }^{140}$ But, even outside EU law, as a species of international law, contemporary treaty practice is growing in the form of 'plurilateral' bespoke pipeline treaties, and EU Member States have participated in this development. Some of these treaties contain obligations erga omnes partes concerning uninterrupted energy flows.

At the same time, the community interest nature of international obligations may be relevant in determining whether suspending compliance with them can be a lawful countermeasure. Some conditions of lawfulness of countermeasures protect community interests per se; others incidentally allow the consideration of the community interest nature of a primary obligation when assessing whether the conditions of lawfulness of a countermeasure have been met. The condition that countermeasures cannot affect fundamental human rights obligations is unlikely to render unlawful countermeasures in the form of interrupting energy supplies to the responsible state, because the human rights obligations of the state taking such countermeasures are unlikely to apply in such extraterritorial situations. However, the condition that countermeasures must be proportionate to the injury suffered may not be met in two cases. First, if the energy-related obligation, performance of which is suspended, is of a community interest nature, this nature is a criterion for measuring proportionality. Second, countermeasures in the form of interrupting energy flows may curtail the ability of the targeted state to comply with its own human rights obligations. 